\title{
Menguji Insider Trading pada Sektor Consumer Goods Indusrty di Bursa Efek Indonesia Periode 2016-2017
}

\author{
Redy Herinanto Albertus ${ }^{\varpi}$ \\ Sekolah Tinggi Ilmu Ekonomi SBI Yogyakarta \\ e-mail: redy.herinanto@gmail.com
}

\begin{abstract}
This study aims to examine the presence of insider trading in the form of information leakage (asymentric information) before the day of the release of the information. Information leaks can be seen from the movement of stock prices in accordance with the direction of information, before the information is released. The analytical tool used in this study is multiple regression to examine the effect of Return on Assets, Current Ratio, and Debt to Equity Ratio on Stock Returns before the release date of the financial statements. By using 10 sample companies from the Consumer Goods Industry sector on the Indonesia Stock Exchange, it was found that there was a positive and significant relationship between Return on Assets and Stock Returns before the release of the financial statements.
\end{abstract}

Keywords: return on asset, current ratio, debt to equity ratio, stock return, asymetric information, insider trading

\begin{abstract}
Abstrak
Penelitian ini bertujuan menguji ada tidaknya insider trading dalam bentuk kebocoran informasi (asymentric information) sebelum hari rilis informasi tersebut. Kebocoran informasi bisa dilihat dari pergerakan harga saham yang sesuai dengan arah informasi sebelum informasi dirilis. Alat analisis yang digunakan dalam penelitian ini adalah regresi linier berganda untuk menguji pengaruh antara Return on Asset, Current Ratio, dan Debt to Equity Ratio terhadap Return Saham sebelum tanggal rilis laporan keuangan. Dengan menggunakan 10 sampel perusahaan dari sektor consumer goods industry di Bursa Efek Indonesia ditemukan hasil bahwa ada hubungan positif dan signifikan antara Return on Asset terhadap Return Saham sebelum hari rilis laporan keuangan.
\end{abstract}

Kata kunci: return on asset, current ratio, debt to equity ratio, stock return, asymetric information, insider trading 


\section{PENDAHULUAN}

Menurut Fama (1969), pasar yang efisien merupakan pasar yang merefleksikan secara penuh segala informasi yang tersedia. Berdasarkan efisiensi tersebut, Fama mengkategorikan pasar menjadi tiga bentuk, yaitu weak, semi strong, dan strong. Pasar dalam bentuk weak mengklaim bahwa harga aset yang diperdagangkan (saham, obligasi, atau properti) sudah mencerminkan semua informasi publik yang tersedia. Pasar dalam bentuk semi strong mengklaim bahwa harga mencerminkan semua informasi yang tersedia untuk umum dan bahwa harga langsung berubah ketika ada informasi publik yang baru. Pasar dalam bentuk strong mengklaim bahwa harga langsung mencerminkan informasi yang bahkan tersembunyi atau informasi orang dalam.

Di dalam pasar efisien, informasi akan menggerakkan harga saham sesuai dengan sifat dari informasi tersebut (berita baik atau berita buruk). Pergerakan harga saham akibat informasi tersebut akan memberikan nilai tambah kepada investor. Namun dari berbagai penelitian baik di negera maju dengan pasar saham yang sudah maju dan di negera berkembang dengan emerging market, menunjukkan belum adanya konsistensi mengenai hasil penelitian terkait pengaruh informasi terhadap harga saham tersebut. Salah satu informasi yang bisa mempengaruhi pergerakan pasar saham adalah rilis laporan keuangan.

Analisis fundamental saham adalah proses menganalisis kesehatan laporan keuangan, keunggulan kompetitif perusahaan, keunggulan manajemen, dan persaingan dalam pasar atau industri. Ketika diterapkan pada transaksi futures dan forex, analisis fundamental berfokus pada keadaan ekonomi secara keseluruhan, dan mempertimbangkan faktor-faktor termasuk suku bunga, produksi, pendapatan, data pekerjaan, Produk Domestik Bruto, data perumahan, data manufaktur, dan manajemen. Analisis fundamental menyatakan bahwa pasar mungkin terlalu murah atau terlalu tinggi dalam menentukan harga sekuritas dalam jangka pendek tetapi harga wajar sekuritasnya pada akhirnya akan tercapai. Keuntungan dapat dibuat dengan membeli (long) atau menjual (short) sekuritas pada harga pasar yang salah dan kemudian menunggu pasar untuk menyesuaikan harga saham sesuai dengan harga wajarnya.

Studi literatur menunjukkan bahwa laporan keuangan emiten banyak dijadikan dasar bagi investor dalam melakukan keputusan investasi. Banyak investor bergantung pada laporan keuangan emiten sebagai panduan menyusun portofolio investasi mereka.Informasi bisa menjadi pedoman bagi semua investor jika informasi tersebut terdistribusi secara adil, merata, dan tepat waktu kepada setiap investor. Realita di dalam dunia pasar modal adalah terkadang informasi tersebut tidak terbagi secara adil, merata, dan tepat waktu kepada setiap investor. Investor besar atau sering disebut investor institusi, dengan sumber daya yang lebih besar seringkali mampu memperoleh informasi terlebih dahulu dibandingkan dengan investor kecil atau investor retail. Ketidaksimetrisan dalam penyebaran informasi ini disebut sebagai asymetric information.

Grossman dan Stiglitz (1980) menunjuk ketidakmungkinan pasar yang efisien secara informasi. Argumen mereka adalah jika harga pasar saham mencerminkan semua informasi tentang harga saham, maka tidak ada yang akan meneliti saham, karena menimbulkan biaya, tapi menerima harga pasar sebagai estimasi terbaik atas nilai riil saham. Lebih lanjut Grossman dan Stiglitz (1980) menyatakan bahwa tidak mungkin terjadi kondisi kompetitif equilibrium, didefinisikan sebagai kondisi dimana harga pasar dapat menghilangkan kesempatan untuk melakukan arbitrase. Dalam proses mengambil peluang melalui arbitrase 
pasar akan selalu menimbulkan biaya, sehingga asumsi bahwa pasar selalu dalam kondisi equilibrium dan terarbitrase dengan sempurna akan menjadi tidak konsisten dengan fakta bahwa proses arbritase pasar selalu menimbulkan biaya.

Proses arbitrase dalam pasar saham bisa diuji dengan melihat apakah harga saham sudah bergerak sebelum informasi dirilis oleh emiten. Pergerakan harga saham sebelum adanya rilis informasi mengindikasikan bahwa ada investor besar atau investor institusi dengan kapital yang besar sudah tahu konten informasi sebelum dirilis. Kondisi ini sering disebut sebagai praktek insider trading.

Di Indonesia, praktik insider trading dilarang berdasarkan Undang-Undang No. 8 tahun 1995 tentang pasar modal. Berdasarkan undang-undang No. 8 tahun 1995, yang dimaksud dengan insider yaitu orang yang bekerja di emiten atau perusahaan publik dan mengetahui informasi dalam perusahaan yang tidak diketahui publik. Secara luas, insider tidak terbatas orang yang bekerja di emiten atau perusahaan publik, tetapi adalah setiap investor yang sudah mendapatkan informasi sebelum dirilis.

Penelitian ini ingin menguji apakah asymetric information menyebabkan adanya insider trading. Penelitian dilakukan pada perusahaan yang termasuk dalam sektor Consumer Goods Industry di Bursa Efek Indonesia periode 2016-2017. Indikasi adanya tidaknya insider trading adalah pergerakan harga abnormal dalam bentuk hubungan yang kuat antara pergerakan harga saham terhadap informasi sebelum informasi tersebut dirilis. Secara umum, informasi laporan keuangan yang menjadi acuan investor dalam keputusan investasi adalah informasi tentang tingkat pengembalian atau return, dan tingkat resiko. Tingkat pengembalian dalam ekspektasi investor bisa dilihat dari tingkat profitabilitas perusahaan, sedangkan tingkat resiko dalam ekspektasi investor bisa dilihat dari tingkat likuiditas perusahaan. Dalam penelitian ini, tingkat profitabilitas akan di proxy kan dengan Return On Asset (ROA), sedangkan tingkat likuiditas akan di proxy kan dengan Current Ratio (CR), dan tingkat leverage akan di proxy kan dengan Debt To Equity Ratio (DER). Variabel harga saham akan di proxy kan dengan return saham.

Untuk melihat secara lebih mendalam, penelitian ini akan membandingkan adanya hubungan Return On Asset, Current Ratio, dan Debt to Equity Ratio terhadap Return Saham sebelum rilis informasi. Bagi investor/ praktisi pasar modal penelitian ini bermanfaat untuk melihat ada tidaknya indikasi insider trading pada perdagangan saham Sektor Consumer Goods Industry di Bursa Efek Indonesia. Bagi keilmuan, penelitian ini berkontribusi memperkaya referensi mengenai topik asymetric information dan insider trading, mengingat topik ini masih jarang dijadikan obyek penelitian.

Dalam pasarmodal, proses perdagangan efek (saham dan obligasi) terjadi melalui tahapan pasar perdana kemudian pasar sekunder. Pasar perdana adalah penjualan perdana saham dan obligasi oleh emiten kepada para investor, yang terjadi pada saat Initial Public Offering atau penawaran umum perdana. Kedua pihak yang saling memerlukan ini tidak bertemu secara dalam bursa tetapi melalui pihak perantara seperti dijelaskan di atas. Dari penjualan saham dan efek di pasar perdana inilah, pihak emiten memperoleh dana yang dibutuhkan untuk mengembangkan usahanya. Pasar sekunder adalah pasar yang terjadi sesaat atau setelah pasar perdana berakhir. Setelah saham dan obligasi dibeli investor dari emiten pada saat IPO, maka investor tersebut menjual kembali saham dan obligasi kepada investor lainnya, baik dengan tujuan mengambil untung dari kenaikan harga (capital gain) maupun untuk menghindari kerugian (capital loss). 
Perdagangan di pasar sekunder inilah yang secara reguler terjadi di bursa efek setiap hari bursa.

\section{Hipotesis Pasar Efisien}

Pergerakan harga saham, menurut teori bergerak berdasarkan informasi. Teori harga saham bergerak berdasarkan informasi dikemukakan oleh Fama (1969) dan Fama et al (1969). Menurut Fama (1969), pasar yang efisien merupakan pasar yang merefleksikan secara penuh segala informasi yang tersedia. Berdasarkan efisiensi tersebut, Fama mengkategorikan pasar menjadi tiga bentuk, yaitu weak, semi strong, dan strong.

Pasar dalam bentuk weak mengklaim bahwa harga aset yang diperdagangkan (saham, obligasi, atau properti) sudah mencerminkan semua informasi publik yang tersedia. Pasar dalam bentuk semi strong mengklaim bahwa harga mencerminkan semua informasi yang tersedia untuk umum dan bahwa harga langsung berubah ketika ada informasi publik yang baru. Pasar dalam bentuk strong mengklaim bahwa harga langsung mencerminkan informasi yang bahkan tersembunyi atau informasi orang dalam.

\section{Ketidakmungkinan Pasar Efisien Secara Informasi}

Grossman dan Stiglitz (1980) menunjuk ketidakmungkinan pasar yang efisien secara informasi. Argumen mereka adalah jika harga pasar saham mencerminkan semua informasi tentang harga saham, maka tidak ada yang akan meneliti saham, karena menimbulkan biaya, melainkan menerima harga pasar sebagai estimasi terbaik atas nilai riil saham.

Lebih lanjut Grossman dan Stiglitz (1980) menyatakan bahwa tidak mungkin terjadi kondisi kompetitif equilibrium, didefinisikan sebagai kondisi dimana harga pasar dapat menghilangkan kesempatan untuk melakukan arbitrase. Dalam proses mengambil peluang melalui arbitrase pasar akan selalu menimbulkan biaya, sehingga asumsi bahwa pasar selalu dalam kondisi equilibrium dan terarbitrase dengan sempurna akan menjadi tidak konsisten dengan fakta bahwa proses arbritase pasar selalu menimbulkan biaya.

Dukungan terhadap argumentasi Grossman dan Stiglitz (1980) tersebut terwujud dalam praktek industri pasar modal dimana perusahaan sekuritas banyak menerbitkan riset rekomendasi analis yang mana dalam proses riset tersebut akan timbul biaya dan dalam rekomendasi analis tersebut termuat informasi informasi baru yang relevan yang bisa mempengaruhi kinerja perusahaan, dan pada akhirnya mempengaruhi kinerja sahamnya di pasar.

\section{Analisis Fundamental}

Analisis fundamental menyatakan bahwa pasar mungkin terlalu murah atau terlalu tinggi dalam menentukan harga sekuritas dalam jangka pendek tetapi harga wajar sekuritasnya pada akhirnya akan tercapai. Keuntungan dapat dibuat dengan membeli (long) atau menjual (short) sekuritas pada harga pasar yang salah dan kemudian menunggu pasar untuk menyesuaikan harga saham sesuai dengan harga wajarnya.

Analisis fundamental saham adalah proses menganalisis kesehatan laporan keuangan, keunggulan kompetitif perusahaan, keunggulan manajemen, dan persaingan dalam pasar atau industri. Ketika diterapkan pada transaksi futures dan forex, analisis fundamental berfokus pada keadaan ekonomi secara keseluruhan, dan mempertimbangkan faktor-faktor termasuk suku bunga, produksi, pendapatan, data pekerjaan, GDP, data perumahan, data manufaktur dan manajemen. Dalam analisis fundamental ada dua pendekatan dasar yang bisa digunakan, analisis top-down dan analisis bottom-up. 
Analisis top-down memulai analisis nya dengan ekonomi global, termasuk indikator ekonomi baik internasional maupun nasional, seperti tingkat pertumbuhan GDP, inflasi, suku bunga, nilai tukar, produktivitas, dan harga energi. Kemudian mempersempit ke analisis industri seperti total penjualan, tingkat harga, efek dari produk pesaing, persaingan asing, dan barrier to entry dari industri. Kemudian analisis dipersempit lagi dengan mencari perusahaan terbaik di industri tersebut. Analisis bottom-up adalah kebalikannya dimana analisis di mulai dari perusahaan, kemudian diperlebar.

Analisis fundamental dilakukan pada data keuangan historis dan data saat ini, tetapi dengan tujuan membuat perkiraan keuangan dimasa depan. Ada beberapa tujuan analisis fundamental:

1. Untuk memperkirakan valuasi saham perusahaan saat ini dan masa datang.

2. Untuk membuat proyeksi bisnis.

3. Untuk mengevaluasi manajemen dan keputusan bisnis internal.

4. Untuk mengkalkulasi resiko.

Investor dan analis yang menggunakan analisis fundamental sebagai metode analisis sekuritas disebut sebagai fundamentalis.

Investor dapat menggunakan salah satu atau kedua metode analisis yang berbeda tapi sebetulnya bisa saling melengkapi ini untuk pemilihan saham. Misalnya banyak investor fundamentalis menggunakan analisis teknikal untuk menentukan harga beli dan harga jual saham. Banyak investor teknikalis menggunakan analisis fundamental untuk membatasi pilihan saham mereka hanya pada saham perusahaan yang baik menurut analisis fundamental.

Perusahaan sekuritas dalam melakukan riset rekomendasi analis saham menggunakan dua metode analisis saham ini dalam rilis rekomendasinya. Analisis teknikal digunakan untuk riset saham yang bersifat day trade dan jangka pendek, dirilis setiap hari dengan target target harga yang berlaku untuk hari itu saja, dan dalam sekali rilis rekomendasi terdapat rekomendasi beberapa saham perusahaan. Analisis fundamental di gunakan untuk riset saham yang sifatnya jangka menengah sampai jangka panjang dengan fokus hanya satu perusahaan yang direkomendasikan. Analis membuat analisis fundamental karena adanya perubahan fundamental yang bisa mempengaruhi kinerja perusahaan di masa datang baik berupa perubahan fundamental ekonomi (tingkat pertumbuhan GDP, inflasi, suku bunga, nilai tukar, produktivitas, dan harga energi), perubahan fundamental industri (total penjualan industri, tingkat harga, efek dari produk pesaing, persaingan asing, dan barrier to entry dari industri), maupun perubahan fundamental perusahaan (perubahan manajemen, perubahan kebijakan dividen, rencana pembiayaan ekspansi).

Satu dari faktor penentu variasi harga saham adalah penilaian sekuritas berdasar ekspektasi pendapatan masa depan. Beberapa makalah menunjukkan bahwa harga saham berkaitan dengan pendapatan saat ini dan pendapatan masa depan Ball dan Brown (1968) dan Beaver et al (1979). Disamping menguji bagaimana harga saham memasukkan informasi tentang pendapatan masa depan, mereka juga menilik pada ketepatan ramalan analis. Sebagai contoh, Brown dan Rozeff (1978) menunjukkan bahwa akurasi ramalan analis lebih tinggi dari model time-series dalam meramal pendapatan perusahaan.

Menurut O'Brien dan Bhushan (1990), karena para analis sering mengkhususkan diri pada suatu industri dan pengetahuan mereka tentang sebuah industri khusus dapat diterapkan pada seluruh perusahaan di dalam industri tersebut, peristiwa khusus perusahaan dapat mempunyai implikasi pada pendapatan perusahaan lain di industri yang sama. 


\section{Asymentric Information}

Asymetric information, juga dikenal sebagai kegagalan informasi, terjadi ketika satu pihak dalam suatu transaksi ekonomi memiliki pengetahuan material yang lebih besar daripada pihak lainnya. Ini biasanya bermanifestasi ketika penjual barang atau jasa memiliki pengetahuan yang lebih besar daripada pembeli, meskipun kebalikannya dimungkinkan. Hampir semua transaksi ekonomi melibatkan asimetri informasi.

Asymetric information adalah spesialisasi dan pembagian pengetahuan dalam masyarakat sebagaimana diterapkan pada perdagangan ekonomi. Sebagai contoh, dokter medis biasanya tahu lebih banyak tentang praktik medis daripada pasien mereka. Lagi pula, melalui pendidikan dan pelatihan yang ekstensif, dokter mengkhususkan diri dalam kedokteran, sedangkan kebanyakan pasien tidak. Prinsip yang sama berlaku untuk arsitek, guru, petugas polisi, pengacara, insinyur, instruktur kebugaran, dan profesional terlatih lainnya.

\section{Insider Trading}

Menurut Bhattacharya et.al (2002) keberadaan dan penegakan aturan insider trading di pasar saham adalah fenomena tahun 1990an. Sebuah studi terhadap 103 negara yang memiliki pasar saham mengungkapkan bahwa 87 dari 103 negara memiliki aturan insider trading, tetapi penegakannya hanya terjadi di 38 negara. Menurut Jaffe (1974) penelitian sebelumnya tentang insider trading telah berfokus pada profitabilitas perdagangan saham yang dilakukan oleh insider trader. Beberapa peneliti telah menyimpulkan bahwa orang dalam dapat memprediksi pergerakan harga saham pergerakan hingga 6 bulan sebelumnya.

Rogoff (1964) misalnya, meneliti 45 perusahaan di mana, dalam satu bulan, ada tiga atau empat insider trader melakukan pembelian saham, dan tidak ada insider yang menjual saham. Rogoff menemukan bahwa tingkat return insider tersebut mampu membukukan tingkat return $9,5 \%$ setiap bulan lebih tinggi dibandingkan index acuan selama 6 bulan berturut turut. Glass (1966) meneliti selama 14 bulan kalender dan memilih delapan sekuritas dengan selisih insider buyer terhadap insider seller terbesar dalam sebulan. Dia menemukan bahwa tingkat return rata-rata sekuritas ini sebesar 10 persen lebih tinggi dibandingkan index acuan selama 7 bulan berturut turut setelah pembelian intensif dilakukan.

\section{Lorie dan Niederhoffer (1968)} menyelidiki kinerja saham ketika ditemukan setidaknya ada dua pembeli lebih banyak dari penjual atau setidaknya dua lebih banyak penjual daripada pembeli yang merupakan insider trader. Mereka menemukan bahwa harga saham dimana bulan sebelumnya ada pembelian intensif membukukan kenaikan lebih tinggi dibandingkan pasar acuan selama 6 bulan setelah pembelian intensif tersebut. Sebaliknya, saham yang mengalami penjualan intensif mengalami penurunan harga lebih tinggi daripada pasar acuan selama 6 bulan setelah penjualan intensif.

Driscoll (1956) meneliti perdagangan oleh insider trader sebelum penurunan dividen dan menemukan bahwa insider trader membeli lebih banyak saham daripada yang mereka jual 6 bulan sebelum pengumuman pennurunan dividen. Dia menyimpulkan bahwa insider trader tidak mengetahui infomasi yang merugikan terkait penurunan dividen.Wu (1963) mengklasifikasikan bulan perdagangan insider trader dalam saham tertentu sebagai bulan pembelian bersih atau bulan penjualan bersih. Mempelajari pergerakan harga dari sekuritas ini di bulan setelah bulan perdagangan, ia menyimpulkan bahwa tidak ada hubungan antara perdagangan insider trader dan pergerakan harga saham.

Scholes (1972) menyelidiki penawaran sekunder, banyak di antaranya dilakukan oleh insider trader,dan menemukan bahwa 
residu sekuritas menurun rata-rata 1 persen pada hari-hari penawaran. Dia menolak hipotesis bahwa residu turun karena tekanan jual dan menyimpulkan bahwa penurunan residu disebabkan oleh keyakinan pasar bahwa emiten memiliki informasi insider yang bersifat merugikan.

Singkatnya, bukti terkait profitabilitas perdagangan yang dilakukan oleh insider trader belum ada konklusi.

\section{Pengembangan Hipotesis}

Pengembangan hipotesis dalam penelitian ini adalah melihat apakah ada anomali dalam pergerakan harga saham. Anomali tersebut terwujub dalam bentuk pergerakan harga saham yang mendahului informasi yang menjadi penyebab pergerakan harga saham tersebut. Pergerakan harga saham yang mendahului informasi tersebut bisa diindikasikan bahwa informasi telah bocor terlebih dahulu kepada investor tertentu (asymetric information) sehingga menyebabkan adanya insider trading.

Menurut Fama (1969), pasar dalam bentuk semi strong mengklaim bahwa harga mencerminkan semua informasi yang tersedia untuk umum dan bahwa harga langsung berubah ketika ada informasi publik yang baru. Insider trading diduga terjadi jika pengaruh laporan keuangan emiten terhadap harga saham terjadi sebelum laporan keuangan tersebut dipulikasikan. Artinya ada sebagian pelaku pasar yang mengetahui laporan keuangan tersebut, sehingga menggerakkan saham nya terlebih dahulu sebelum laporan keuangan dipublikasi secara resmi.

Dengan asumsi adanya insider trader yang mengtahui informasi sebelum dirilis, maka ROA, CR, dan DER berpengaruh terhadap return saham sebelum rilis (karena adanya insider trading). Sehingga hipotesis yang diajukan dalam penelitian ini adalah:
H1: CR berpengaruh positif terhadap return saham sebelum tanggal rilis.

$\mathrm{H} 2$ : ROA berpengaruh positif terhadap return saham sebelum tanggal rilis.

H3: DER berpengaruh negatif terhadap return saham sebelum tanggal rilis.

H4: CR, ROA, DER secara simultan berpengaruh terhadap return saham sebelum tanggal rilis.

\section{METODE PENELITIAN}

\section{Populasi dan Sampel}

Populasi dari penelitian ini adalah seluruh emiten yang termasuk dalam sektor sektor Consumer Goods Industry di Bursa Efek Indonesia periode 2016-2017, jumlah populasi adalah sebanyak 54 emiten. Sampel yang digunakan adalah 10 emiten yang atribut datanya sesuai dengan desain penelitian dengan menggunakan metode purposive sampling. Kriteria purposive sampling untuk menentukan sample adalah sebagai berikut:

1. Emiten yang temasuk dalam sektor Consumer Goods Industry di Bursa Efek Indonesia periode 2016-2017.

2. Emiten yang menerbitkan laporan keuangan kuartalan dari kuartal 12016 sampai dengan kuartal 42017.

3. Emiten yang perdagangan sahamnya di pasar sekunder tidak mengalami suspensi dari Bursa Efek Indonesia mulai 1 Januari 2016 sampa dengan 31 Desember 2017.

4. Emiten yang harga sahamnya di pasar sekunder lebih dari 50 rupiah (tidak menyentuh harga autorejection bawah).

5 Emiten dengan nilai kapitalisasi pasar terbesar di Sektor Consumer Goods Industry di Bursa Efek Indonesia.

6. Untuk menghitung nilai kapitalisasi pasar menggunakan rumus harga saham pada tanggal hari pertama perdagangan saham tahun 2016 (tanggal awal penelitian) dikalikan jumlah saham beredar. 
Sektor "Consumer Goods Industry” di Bursa Efek Indonesia di Bursa Efek Indonesia memiliki 54 emiten. Dari 54 emiten tersebut dipilih $10(18,5 \%)$ sampel emiten dengan kapitalisasi pasar terbesar.

Emiten yang digunakan sebagai sampel adalah sebagai berikut:

1. HMSP (PT. H.M Sampoerna Tbk)

2. MYOR (PT. Mayora Indah Tbk)

3. UNVR (PT. Unilever Indonesia Tbk)

4. ICBP (PT. Indofood CBP Sukses Makmur Tbk)

5. IIKP (PT. Inti Agri Resources Tbk)

6. GGRM (PT. Gudang Garam Tbk)

7. BTEK (PT. Bumi Teknokultura Unggul Tbk)

8. KLBF (PT. Kalbe Farma Tbk)

9. INDF (PT. Indofood Sukses Makmur Tbk)
10. ULTJ (PT. Ultra Jaya Milk Industry Tbk)

Periode sampel data penelitian adalah laporan kuartalan dan harga saham antara Januari 2016 sampai dengan Desember 2017. Jumlah pooling data yang akan terbentuk adalah jumlah emiten sampel dikalikan jumlah laporan keuangan kuartalan setiap emiten dalam periode penelitian yaitu 2016 sampai dengan 2017. Pooling data (N) sebanyak 10 dikalikan 8 sama dengan 80 .

Penelitian ini menggunakan alat analisis regresi linier berganda dengan software SPSS.

\section{HASIL DAN PEMBAHASAN}

Analisis data menggunakan analisis statistik dekriptif dengan tujuan memberikan gambaran suatu data yang dilihat dari rata-rata, standart deviasi, maksimum, dan minimum.

Tabel 1. Statistik Deskriptif

\begin{tabular}{lrrr}
\hline & \multicolumn{1}{l}{ Mean } & \multicolumn{1}{c}{ Std. Deviation } & \multicolumn{1}{l}{ N } \\
Return &,- 0103 &, 24449 & 80 \\
CR & $1,157,261$ & $71,124,345$ & 80 \\
ROA &, 2795 &, 21730 & 80 \\
DER &, 8713 &, 97111 & 80 \\
\hline
\end{tabular}

\section{Pengujian Asumsi Klasik}

\section{Uji Normalitas}

Uji normalitas bertujuan untuk menguji apakah variabel dependan dan variabel independen terdistribusi normal. Uji normalitas akan menggunakan ScatterPlot. Dari hasil uji terlihat bahwa titik titik plotnya mendekati garis, sehingga datanya normal.

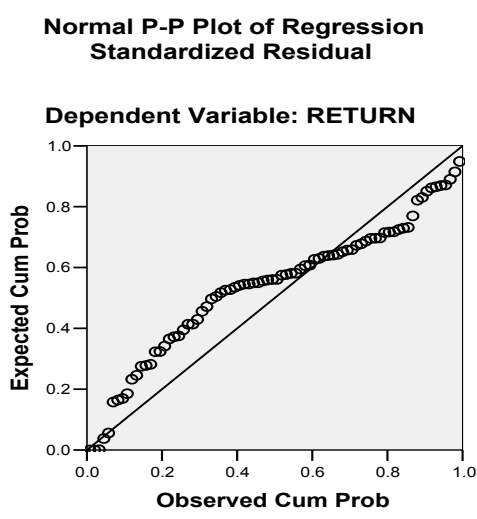

Gambar 1. Uji Normalitas 


\section{Uji Multikolinearitas}

Uji multikolinearitas adalah kondisi dimana salah satu atau lebih dari varibel independen dapat dinyatakan sebagai kombinasi linier dari variabel independen lainnya. Berdasarkan hasil uji multikolinearitas dengan metode VIF, nilai $\mathrm{VIF}<10$. Begitu juga dengan nilai tolerance, semua $>0.1$. Dengan demikian semua variabel bebas tidak terjadi multikolinearitas, sehingga tidak membiaskan interpretasi hasil analisis regresi.

\section{Uji Autokorelasi}

Uji autokorelasi adalah uji untuk melihat adanya faktor pengganggu (error term) pada periode tertentu berkorelasi dengan faktor pengganggu pada periode lain. Faktor pengganggu tidak random. Dari hasil pengujian dihasilkan angka D-W sebesar 2,299. Angka tersebut adalah 1,699 < 2,299 $<2,301$ sehingga dapat dapat disimpulkan model yang diestimasi tidak terjadi autokorelasi.

Tabel 2. Uji Multikolinearitas

\begin{tabular}{|c|c|c|c|c|c|c|c|c|}
\hline \multirow[t]{3}{*}{ Model } & & \multirow{2}{*}{\multicolumn{2}{|c|}{$\begin{array}{l}\text { Unstandardized } \\
\text { Coefficients }\end{array}$}} & \multirow{3}{*}{$\begin{array}{l}\text { Standardized } \\
\text { Coefficients } \\
\text { Beta }\end{array}$} & \multirow[t]{3}{*}{$\mathrm{t}$} & \multirow[t]{3}{*}{.$S i g$} & \multicolumn{2}{|c|}{$\begin{array}{c}\text { Collinearity Sta- } \\
\text { tistics }\end{array}$} \\
\hline & & & & & & & \multirow[t]{2}{*}{ Tolerance } & \multirow[t]{2}{*}{ VIF } \\
\hline & & $B$ & Std. Error & & & & & \\
\hline \multirow[t]{4}{*}{1} & (Constant) & $126,-$ & 046 & & $-2,734$ & 008 & & \\
\hline & $\mathrm{CR}$ & $-5,6 E-006$ & 000 & 016,- & $154,-$ & 878 & 972 & 1,029 \\
\hline & ROA & 458 & 120 & 407 & 3,832 & 000 & 975 & 1,025 \\
\hline & DER & $014,-$ & 027 & $054,-$ & $505,-$ & 615 & 958 & 1,044 \\
\hline
\end{tabular}

a. Dependent Variable: Return

Tabel 3. Uji Autokorelasi

\begin{tabular}{|c|c|c|c|c|c|}
\hline Model & $\mathrm{R}$ & R Square & $\begin{array}{l}\text { Adjusted } \\
\text { R Square }\end{array}$ & $\begin{array}{l}\text { Std. Error of } \\
\text { the Estimate }\end{array}$ & $\begin{array}{l}\text {-Dubin } \\
\text { Watson }\end{array}$ \\
\hline 1 & $403 a$ & 162 & 129 , & 2281566175 & 2,299 \\
\hline
\end{tabular}

a. Predictors: (Constant), DER, ROA, CR

b. Dependent Variable: Return

\section{Regresi Linier Berganda}

Pengujian hipotesis dengan menggunakan Regresi Linier Berganda. Regresi Linier Berganda digunakan untuk mengukur hubungan antara variabel dependen dengan variabel variabel independennya baik secara parsial maupun simultan.
Berdasarkan hasil uji regresi dengan menggunakan excel, persamaan matematis dari regresi penelitian ini adalah sebagai berikut:

$$
\begin{aligned}
\mathrm{Y}= & -0,126-5,6 \mathrm{E}-006 \mathrm{CR}+0,458 \mathrm{ROA}- \\
& 0,14 \mathrm{DER}
\end{aligned}
$$


Tabel 4. Analisis Regresi Berganda

\begin{tabular}{|c|c|c|c|c|c|c|}
\hline \multicolumn{7}{|c|}{ Coefficients } \\
\hline \multirow[t]{3}{*}{ Model } & & \multirow{2}{*}{\multicolumn{2}{|c|}{$\begin{array}{l}\text { Unstandardized } \\
\text { Coefficients }\end{array}$}} & \multirow{3}{*}{$\begin{array}{c}\text { Standardized } \\
\text { Coefficients } \\
\text { Beta }\end{array}$} & \multirow[t]{3}{*}{$t$} & \multirow[t]{3}{*}{.Sig } \\
\hline & & & & & & \\
\hline & & B & Std. Error & & & \\
\hline \multirow[t]{4}{*}{1} & (Constant) & $126,-$ & 046, & & $-2,734$ & 008 \\
\hline & CR & $-5,6 E-006$ & 000, & 016,-- & $154,-$ & 878 \\
\hline & ROA & 458 & 120 & 407 & 3,832 & 000 \\
\hline & DER & 014,- & 027 & 054,- & $505,-$ & 615 \\
\hline
\end{tabular}

a. Dependent Variable: Return

Tabel 5. Uji F

ANOVA

\begin{tabular}{|c|c|c|c|c|c|c|}
\hline & & Sum of & & & & \\
\hline Model & & Squares & df & Mean Square & $\mathrm{F}$ & .Sig \\
\hline \multirow[t]{3}{*}{1} & Regression & 766 & 3 & 255 & 4,904 & $004 a$ \\
\hline & Residual & 3,956 & 76 & 052 & & \\
\hline & Total & 4,722 & 79 & & & \\
\hline
\end{tabular}

a. Predictors: (Constant), DER, ROA, CR

b. Dependent Variable: Return

Tabel 6. Uji Koefisien Determinasi

\begin{tabular}{ccccc}
\multicolumn{6}{c}{ Model Summary } \\
\hline Model & $\mathrm{R}$ & $\mathrm{R}$ Square & $\begin{array}{l}\text { Adjusted } \\
\mathrm{R} \text { Square }\end{array}$ & $\begin{array}{c}\text { Std. Error of } \\
\text { the Estimate }\end{array}$ \\
\hline 1 &, $403 a$ &, 162 &, 129 &, 2281566175 \\
\hline
\end{tabular}

a. Predictors: (Constant), DER, ROA, CR

b. Dependent Variable: Return

Pada hipotesis pertama, ada pengaruh negatif CR (-5.6E-006; signifikansi 0.875 $>0.05)$ terhadap return saham sebelum tanggal rilis, akan tetapi pengaruh tersebut tidak signifikan. Sehingga Ha ditolak, dan H0 diterima (CR tidak berpengaruh positif terhadap return saham sebelum tanggal rilis).

Pada hipotesis kedua, ada pengaruh positif dan signifikan ROA (0.458; signifikansi $0.000<0.05)$ terhadap return saham sebelum tanggal rilis. Sehingga H0 ditolak dan Ha diterima (ROA berpengaruh positif dan signifikan terhadap return saham sebelum tanggal rilis).
Pada hipotesis ketiga, ada pengaruh negatif DER (-0.014; signifikansi 0.615) terhadap return saham sebelum tanggal rilis, akan tetapi pengaruh tersebut tidak signifikan. Sehingga Ha ditolak, dan H0 diterima (DER tidak berpengaruh negatif terhadap return saham sebelum tanggal rilis).

Pada hipotesis keempat, ada pengaruh signifikan CR, ROA DER secara simultan terhadap return saham sebelum tanggal rilis (signifikansi $0.004<0.05$ ). Sehingga H0 ditolak, dan Ha diterima (CR, ROA, DER secara simultan berpengaruh signifikan terhadap return saham sebelum tanggal rilis). 
Angka $\mathrm{R}$ square sebesar 0,162 menunjukkan bahwa variabel dependen dalam penelitian ini (return saham), hanya 16,2\% dapat dijelaskan oleh variabel independen (CR, ROA, dan DER), sedangkan sisanya sebesar $83,8 \%$ dijelaskan oleh variabel lain di luar model.

\section{KESIMPULAN DAN SARAN}

Berdasarkan analisis dan pembahasan yang telah dilakukan di bab sebelumnya, maka kesimpulan penelitian ini adalah sebagai berikut:

1. CR berpengaruh negatif, tetapi tidak signifikan terhadap return saham pada sektor Consumer Goods Industry di Bursa Efek Indonesia periode 20162017 sebelum rilis laporan keuangan. Sehingga dapat disimpulkan tidak ada kebocoran informasi (asymetric information) yang menimbulkan adanya insider trading.

2. ROA berpengaruh positif terhadap return saham pada sektor Consumer Goods Industry di Bursa Efek Indonesia periode 2016-2017 sebelum rilis laporan keuangan, dan pengaruh tersebut signifikan. Sehingga dapat disimpulkan ada kebocoran informasi (asymetric information) yang menimbulkan adanya insider trading.

3. DER berpengaruh negatif, tetapi tidak signifikan terhadap return saham pada sektor Consumer Goods Industry di Bursa Efek Indonesia periode 20162017 sebelum rilis laporan keuangan. Sehingga dapat disimpulkan tidak ada kebocoran informasi (asymetric information) yang menimbulkan adanya insider trading.

4. CR, ROA, DER secara simultan berpengaruh signifikan terhadap return saham pada sektor "Consumer Goods Industry" di Bursa Efek Indonesia periode 2016-2017 sebelum rilis laporan keuangan. Sehingga dapat disimpulkan ada kebocoran informasi (asymetric information) yang menimbulkan adanya insider trading.

Penelitian ini menyarankan beberapa hal yaitu:

1. Dari kesimpulan diketahui bahwa secara simultan CR, ROA, DER berpengaruh signifikan terhadap return saham sebelum rilis informasi. Hasil tersebut mengindikasikan bahwa ada kebocoran informasi LK sebelum rilis resmi. Dari hasil penelitian juga diketahui bahwa hanya ROA berpengaruh positif dan signifikan terhadap return saham sebelum rilis informasi, sedang variabel lainnya (CR, DER) tidak berpengaruh. Di dalam informasi LK yang bocor tersebut, terkandung informasi terkait rasio CR (Likuiditas), ROA (Profitabilitas), dan DER (Solvabilitas). Dapat disimpulkan insider trader memilih variabel ROA (Profitabilitas) untuk memutuskan melakukan keputusan trading berdasarkan kebocoran informasi LK tersebut.

2. Penelitian selanjutnya terkait dengan insider trading difokuskan pada rasio Profitabilitas dan Performance dari LK. Regulator (Bursa Efek Indonesia dan Otoritas Jasa Keuangan) perlu meningkatkan pengawasan terkait transaksi yang berpotensi merugikan investor secara khusus, dan pasar modal Indonesia secara umum. Aturan terkait insider trading tertuang dalam UU, akan tetapi belum ada penegakan aturan tersebut di Indonesia. Penegakan yang tidak ada tersebut kemungkinan karena sulitnya mencari bukti terkait dengan insider trading. Penelitian semacam ini bisa menjadi indikasi awal terjadinya insider trading. 


\section{REFERENSI}

Ball, R. dan P. Brown, 1968, An Empirical Evaluation Of Accounting Income Numbers, Journal of Accounting Research.

Ball, R. S. P. Kothari, dan A. Robin, 1998, The Effect Of International Institutional Factors On Properties Of Accounting Earnings, Working paper, University of Rochester.

Bhattacharya, U. dan H. Daouk, 2002, The World Price of Insider Trading, The Journal of Finance, Vol. VII, No. 1.

Beaver, W., R. Clarke dan W. Wright, 1979, The Association Between Unsystematic Security Returns And The Magnitude Of Earnings Forecast Errors, Journal of Accounting Research.

Brown, L.D., dan M.S. Rozeff, 1978, The superiority of analyst forecast as measure of expectations: Evidence from earnings, Journal of Finance.

Donald L. Rogoff, 1964. The Forecasting Properties Of Insiders' Transactions, Journal of Finance, American Finance Association, Vol. 19(4), pages 697698, December.

Driscoll, TE. 1956, Some aspects of corporate insider stock holdings and trading under Section, Securities and Exchange Act of 1934. M.B.A. Thesis. Univ. of Pennn

Fama, E.F, 1969, Eficient Capital Market: A Review Of Theory And Empirical Work, 1969.
Fama, Fisher, Jensen, Roll, The Adjustment of Stock Prices to New Information, 1969.

Gary, S. Glass, 1966, Extensive Insider Accumulation as an Indicator of Near Term Stock Price Performance, Ph.D. diss., Ohio State University.

Grossman, S. dan J. Stglitz, 1980, On The Impossibility Of Informationally Efficient Markets, American Economic Review, 70.

Grossman, S. and Stiglitz, J., 1980, Stockholder Unanimity In Making Production and Financial Decisions, Quarterly Journal of Economics.

James, H., Lorie and Victor Niederhoffer, 1968, Predictive and Statistical Properties of Insider Trading, Journal of Law and Economics, Vol. 11, No. 1, (Apr.,), pp. 35-53.

Jeffrey, F. Jaffe, 1974, Special Information and Insider Trading, The Journal of Business, Vol. 47, No. 3. July.

Myron, S. Scholes, 1972, The Market for Securities: Substitution versus Price Pressure and the Effects of Information on Share Price, Journal of Business, 45 (April), 179-211.

$\mathrm{Wu}, \mathrm{HK} .1963$, Corporate insider trading profitability and stock price movement, PhD Diss., Univ. Penn. 